\title{
Wear behavior of oxidized Ti-48Al-2Cr-2 Nb (at. \%), Ti-6Al-4V and Cp-Ti under dry and lubricated conditions
}

\author{
Carlos R. Ramos-Saenz ${ }^{1}$, Paul A. Sundaram ${ }^{2}$ \\ 1. Ponce School of Medicine and Health Sciences, Ponce, USA. 2. Department of Mechanical Engineering, University of \\ Puerto Rico, Mayagüez, USA.
}

Correspondence: Paul A. Sundaram. Address: Department of Mechanical Engineering, University of Puerto Rico, Mayaguez, PR 00680, USA. Email: paul.sundaram@upr.edu

Received: August 26, 2015

Accepted: September 21, 2015

Online Published: September 28, 2015

DOI : $10.5430 /$ jbei.v2n1p39

URL: http://dx.doi.org/10.5430/jbei.v2n1p39

\section{Abstract}

Gamma titanium aluminide (gamma-TiAl) is a titanium alloy which contains no vanadium and appears to have potential for biomedical applications such as joint prostheses. The tribomechanical properties of Ti-48Al-2Cr-2Nb (at. \%) (gamma$\mathrm{TiAl}$ ) subjected to oxidation in air at $500^{\circ} \mathrm{C}$ and $800^{\circ} \mathrm{C}$ were determined by standard wear tests using a hardened stainless steel (SS) pin in a linearly reciprocating mode under both dry and lubricated (Ringer's solution) media. Similar properties for CP-Ti and Ti-6Al-4V were measured for comparison. The lowest mean mass loss was obtained for oxidized gamma-TiAl alloy indicating excellent wear resistance. The dominant wear mechanism on all the Ti alloy samples was abrasion. The oxidation temperature had a minimal effect on the wear of gamma-TiAl but was significant for the other two alloys.

\section{Key words}

Biomedical, Intermetallic, Oxidation, Titanium, Wear, Joint prosthesis

\section{I ntroduction}

A number of studies have considered the wear behavior of joint arthroplasties and prostheses and are in general agreement that the debris resulting from implant wear is one of the primary reasons for aseptic loosening in implants ${ }^{[1-4]}$. A number of causes, including improper initial fixation and peri-implant tissue osteolysis resulting from wear debris, have been attributed to the phenomenon of implant loosening ${ }^{[5]}$. Titanium-based materials which have become popular as orthopedic implants have been well characterized and there has been a sizable increase in their use worldwide for medical purposes ${ }^{[6]}$. Titanium's low modulus of elasticity (110 GPa), which is much lower than stainless steel or cobalt-based alloys used as implants and relatively much more similar to that of cortical bone ${ }^{[7]}$ is expected to lead to less stress shielding in the peri-implants in bone. Even though titanium-based alloys are now common biocompatible materials for implants because they also possess outstanding mechanical properties, micro-motion between the implant and bone tissue resulting in the generation of wear debris followed by implant loosening in total hip arthroplasty of these titanium based alloys even in early applications has been recognized ${ }^{[8-10]}$. Rapid osseointegration is hence required to catalog the surgery after 
implantation as a clinical success ${ }^{[11,12]}$. The biological fixation between the implant and the bone also depends on the implant's surface chemistry and topography ${ }^{[13-16]}$. A titanium-based alloy which is being currently studied for possible implant application is Ti-48Al-2Nb-2Cr (at. \%) ${ }^{[17-19]}$. Oxidation of this alloy (henceforth also referred to as gamma-TiAl) at $500^{\circ} \mathrm{C}$ and $800^{\circ} \mathrm{C}$ has shown contrasting behavior in terms of cytotoxicity of the oxidized surfaces ${ }^{[20]}$. A number of other studies have characterized wear behavior of both gamma titanium aluminides and their oxidized surfaces ${ }^{[21-23]}$ albeit under rotating pin-on-disk configurations, although it is obvious that reciprocatory motion is more representative of the actual micro-motion at the bone-implant interface. Hence the principal aim of this study is to understand the wear behavior and tribological properties of gamma-TiAl for reciprocatory sliding wear both in the unoxidized and oxidized conditions (at $500^{\circ} \mathrm{C}$ and $800^{\circ} \mathrm{C}$ ) and under both dry and lubricated conditions, keeping in mind primarily implant applications. An earlier study characterized wear behavior for the above material using a novel bone pin made from a bovine femur ${ }^{[24]}$, where the wear was completely concentrated on the bone. In this study, a harder SS pin is used to produce wear in the oxide layer generated on gamma-TiAl. For comparison, Ti-6Al-4V and CP (commercially pure) Ti are also tested.

\section{Experiments}

The as-received Ti-48Al-2Nb-2Cr (at. \%) (gamma-TiAl), Ti-6Al-4V and CP Ti alloys were obtained in the form of $25 \mathrm{~mm}$ rods from which $1 \mathrm{~mm}$ thick disks were extracted using electric-discharge machining (EDM). The samples were ground up to 600 grit finish using emery paper. For each alloy type, two disks were oxidized in air at $500^{\circ} \mathrm{C}$ and two other disks at $800^{\circ} \mathrm{C}$ for one hour in a rapid heating furnace and cooled to room temperature before wear testing. The tests were performed on the oxide on either side of the disks in both dry and lubricated environments using a tribometer in linear reciprocating mode resulting in four tests for each experimental condition. Unoxidized disks were tested under the same conditions for comparison. Separately, wet tests were also carried out for oxidized and unoxidized disks in Ringer's solution. A total of 24 disks, two each of gamma-TiAl, Ti-6Al-4V and CP-Ti oxidized at $500^{\circ} \mathrm{C}$ and two each of the same materials oxidized at $800^{\circ} \mathrm{C}$ under dry conditions and the same set repeated under wet or lubricated conditions were used during the experiments. The oxidizing temperatures were selected based on earlier work that aluminum oxide is preferentially formed on gamma-TiAl at $500^{\circ} \mathrm{C}$ for short oxidation times while a mixed oxide consisting of predominantly titanium oxide is formed at $800^{\circ} \mathrm{C}^{[25]}$.

Wet and dry tests using $440 \mathrm{C}$ stainless steel (SS) pins (3.175 mm diameter balls with a hardness of $58 \mathrm{HRC}$ min.) were carried out for thirty minutes under an externally applied force of $3 \mathrm{~N}$ perpendicular to the flat surface of the disks. The sliding velocity was set to $900 \mathrm{~mm} / \mathrm{min}$ at $5 \mathrm{~Hz}$ with $5 \mathrm{~mm}$ tangential sliding amplitude. All lubricated tests were performed by submerging the disks in fresh lactated Ringer's solution at ambient temperature $\left(25^{\circ} \mathrm{C} \pm 5^{\circ} \mathrm{C}\right)$. The Ringer's solution consisted of $600 \mathrm{mg} \mathrm{NaCl}, 310 \mathrm{mg} \mathrm{C} \mathrm{H}_{5} \mathrm{NaO}_{3}, 30 \mathrm{mg} \mathrm{KCl}$, and $20 \mathrm{mg} \mathrm{CaCl}_{2}$ per $100 \mathrm{~mL}$ with a pH of approximately 7.4. The disks were completely immersed in Ringer's solution for the lubricated tests. Non-lubricated tests were carried out at room temperature $\left(25^{\circ} \mathrm{C} \pm 5^{\circ} \mathrm{C}\right)$ and relative humidity of $67 \% \pm 2 \%$. The weight of each sample and SS pin was measured before and after each test using a five-digit analytical balance with a reliability of $0.01 \mathrm{mg}$. A Carl-Zeiss Gemini 1530 SEM and a Nikon Eclipse model 80i optical microscope were used to capture images of the surface topography and wear tracks. SEM images were obtained using secondary electron imaging from $6 \mathrm{KeV}$ to $25 \mathrm{KeV}$ whereas the EDS data was captured using back-scattered electron mode at $15 \mathrm{KeV}$. The dominant wear mechanisms were determined by analyzing these images. With the EDS analysis, an approximate elemental composition of the oxide layer formed on gamma-TiAl was obtained.

\section{Results and discussions}

Surface images of the oxidized gamma-TiAl samples are depicted in Figure 1. The surface topography is nodular for the oxide formed at $800^{\circ} \mathrm{C}$ compared to the relatively smooth oxide layer at $500^{\circ} \mathrm{C}$. As expected, the oxide layer on gamma-TiAl at $500^{\circ} \mathrm{C}$ appears to be a mixed titanium aluminum oxide rich in aluminum oxide based on EDS 
measurements (see Figure 2). Semi-quantitative analysis indicated the oxide composition to consist of 12.97 at. \% Ti, 15.25 at. \% $\mathrm{Al}$ and 71.79 at. \% O. The trace amounts of $\mathrm{Cr}, \mathrm{Nb}$ and $\mathrm{Cu}$ which appear in the EDS were too small to be quantified using EDAX analysis. While the presence of $\mathrm{Cr}$ and $\mathrm{Nb}$ is expected since these elements are constituents of gamma-TiAl, $\mathrm{Cu}$ was introduced as an impurity during the wire EDM process where brass wire was used to cut the disks. At $800^{\circ} \mathrm{C}$, a nodular oxide structure is formed on gamma-TiAl as a Ti-Al-O mixed oxide with $\mathrm{Nb}$ and $\mathrm{Cr}$ probably incorporated in this defect structure as determined from EDS analysis confirmed by earlier reports ${ }^{[16,21]}$. EDAX analysis indicated an oxide composition of 13.19 at. \% Ti, 16.44 at. \% Al, 67.84 at. \% O, 0.49 at. \% Nb, 0.41 at. \% Cr and 1.62 at. \% $\mathrm{Cu}$ for gamma-TiAl oxidized at $800^{\circ} \mathrm{C}$. The oxide composition at $500^{\circ} \mathrm{C}$ and $800^{\circ} \mathrm{C}$ are similar except for $\mathrm{Nb}, \mathrm{Cr}$ and $\mathrm{Cu}$ which were detected for the latter.

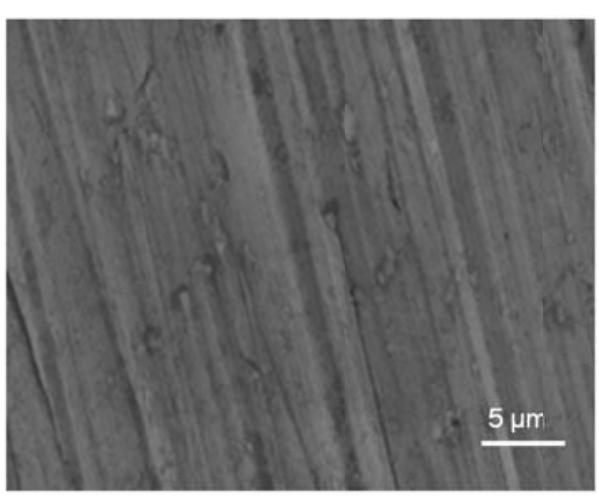

(a)

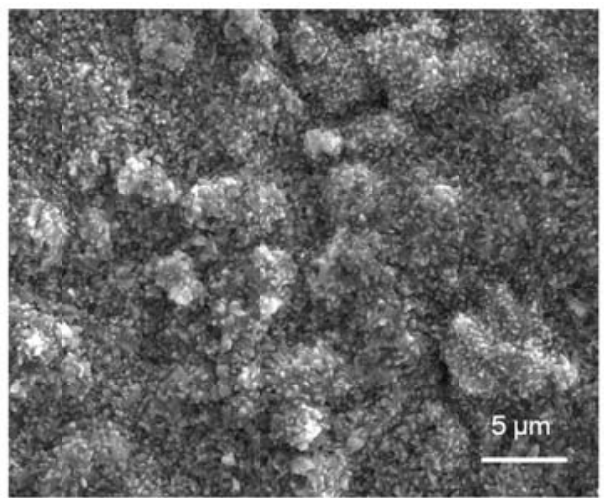

(b)

Figure 1. SEM images of the surface topography of gamma-TiAl oxidized at (a) $500^{\circ} \mathrm{C}$ and (b) $800^{\circ} \mathrm{C}$. The latter has a nodular appearance.

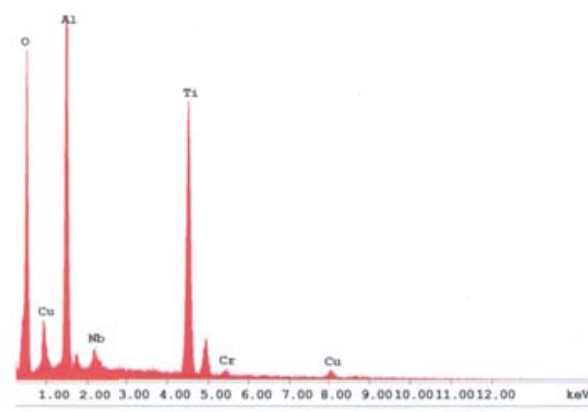

(a)

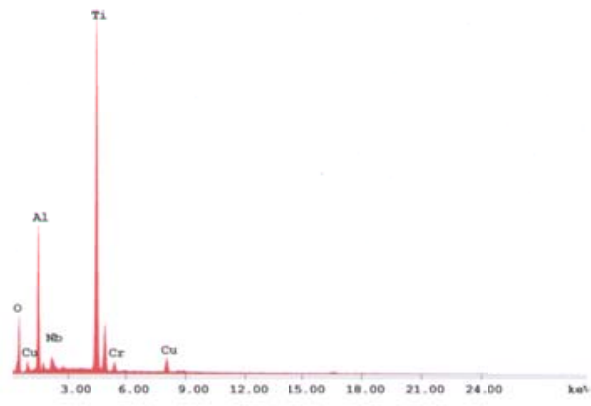

(b)

Figure 2. Energy dispersive spectra for the mixed oxides formed on gamma-TiAl at (a) $500^{\circ} \mathrm{C}$ and (b) $800^{\circ} \mathrm{C}$.

\subsection{Tests on oxidized samples in dry medium}

Figure 3 shows the coefficient of friction (COF) values with number of cycles for the Ti-base materials against the SS pin in dry medium. For these tests, the humidity levels were constantly monitored and the ambient temperature was maintained fairly constant. From this figure, the COF values for the three alloys showed variability with increasing number of cycles, even though Figure 3 exhibits the tendency of a rapidly narrowing convergence at around 1,000 cycles. The COF values for all three alloys were similar at the end of the testing period for both oxidation temperatures. The lower initial COF values for $\mathrm{CP}-\mathrm{Ti}$ and $\mathrm{Ti}-6 \mathrm{Al}-4 \mathrm{~V}$ both oxidized at $500^{\circ} \mathrm{C}$ is probably due to the smoother oxide layer formed on these materials. The oxidized samples of gamma-TiAl $\left(500^{\circ} \mathrm{C}\right.$ and $\left.800^{\circ} \mathrm{C}\right)$ showed similar $\mathrm{COF}$ values of about 0.8 . As 
observed, the COF for gamma-TiAl oxidized at $500^{\circ} \mathrm{C}$ varies quite erratically, probably as a result of the cyclic wear process which generates debris that adheres to the surface, spalls off and gets welded again because of the intense local temperatures. On the contrary, the behavior of the $\mathrm{COF}$ for gamma-TiAl at $800^{\circ} \mathrm{C}$ changed smoothly and at the end remained almost constant. The COF of the CP-Ti samples reached a value of 0.90 for samples oxidized at $500^{\circ} \mathrm{C}$ and 0.92 for those oxidized at $800^{\circ} \mathrm{C}$. The mean volume loss and mean mass loss for each of the alloys are shown in Table 1 and Table 2 respectively. All the titanium-base materials appear to suffer similar mean volume loss. The fact that the ball pin's contact area remained unchanged after the tests indicates that instead of enlarging the wear track, the contact pin traveled deeper (ploughing). From Figure 4 it can be seen that the SS pin caused greater abrasion on the gamma-TiAl oxidized at $500^{\circ} \mathrm{C}$ where a predominantly aluminum oxide layer is expected to form ${ }^{[25]}$. In all other cases, transfer of some material from the SS pin is also evident from the rust-colored marks on the wear track. Therefore, the mean loss in volume and the mean mass loss values may be an underestimation in the loss in materials during sliding wear since the metal transferred from the SS pin is being welded onto the substrate surface. Clearly, gamma-TiAl appears to lose the least amount of mass for both of the oxidized conditions indicating the adherent nature of the oxide film formed in this case.

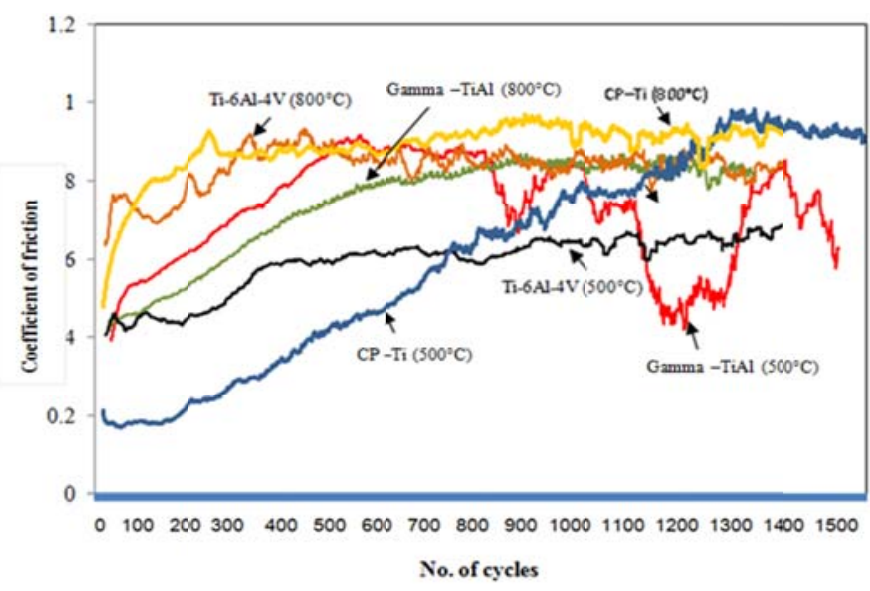

Figure 3. COF versus number of cycles of oxidized Ti-base materials against stainless steel pin at $3 \mathrm{~N}$ normal load in non-lubricated medium, $5 \mathrm{~Hz}$ frequency, and $10 \mathrm{~mm}$ displacement.

Table 1. Mean $(\mathrm{n}=4)$ volume loss $\left(\mathrm{cm}^{3}\right)$ for Ti alloys after wear tests for different conditions

\begin{tabular}{|c|c|c|c|c|}
\hline \multirow{3}{*}{ Materials } & \multicolumn{2}{|c|}{ Mean Volume Loss $\left(\mathrm{cm}^{3}\right)$} & \multicolumn{2}{|c|}{ Mean Volume Loss $\left(\mathrm{cm}^{3}\right)$} \\
\hline & \multicolumn{2}{|l|}{ Dry } & \multicolumn{2}{|c|}{ Lubricated } \\
\hline & $500^{\circ} \mathrm{C}$ & $800^{\circ} \mathrm{C}$ & $500^{\circ} \mathrm{C}$ & $800^{\circ} \mathrm{C}$ \\
\hline$\gamma$-TiAl & 0.00098 & 0.00098 & 0.0012 & 0.00100 \\
\hline Ti-6Al-4V & 0.00082 & 0.00097 & 0.0012 & 0.00138 \\
\hline CP-Ti & 0.00093 & 0.00184 & 0.00103 & 0.00142 \\
\hline
\end{tabular}

Table 2. Mean ( $\mathrm{n}=4$ ) mass loss $(\mathrm{g})$ for Ti alloys after wear tests under different tribological conditions and oxidation temperatures

\begin{tabular}{|c|c|c|c|c|c|c|}
\hline \multirow{3}{*}{ Materials } & \multirow{2}{*}{\multicolumn{2}{|c|}{$\begin{array}{l}\text { Mean Mass Loss (g) } \\
\text { Dry }\end{array}$}} & \multirow{2}{*}{\multicolumn{2}{|c|}{$\begin{array}{l}\text { Mean Mass Loss (g) } \\
\text { Lubricated }\end{array}$}} & \multicolumn{2}{|c|}{ Mean Mass Loss (g) } \\
\hline & & & & & \multirow{2}{*}{$\begin{array}{l}\text { Dry } \\
\text { Unoxidized }\end{array}$} & \multirow{2}{*}{$\begin{array}{l}\text { Lubricated } \\
\text { Unoxidized }\end{array}$} \\
\hline & $500^{\circ} \mathrm{C}$ & $800^{\circ} \mathrm{C}$ & $500^{\circ} \mathrm{C}$ & $800^{\circ} \mathrm{C}$ & & \\
\hline$\gamma$-TiAl & 0.00362 & 0.00364 & 0.00390 & 0.00369 & 0.00769 & 0.00682 \\
\hline Ti-6Al-4V & 0.00428 & 0.00823 & 0.00472 & 0.00609 & 0.00916 & 0.00840 \\
\hline CP-Ti & 0.00420 & 0.00829 & 0.00466 & 0.00640 & 0.00908 & 0.00929 \\
\hline
\end{tabular}




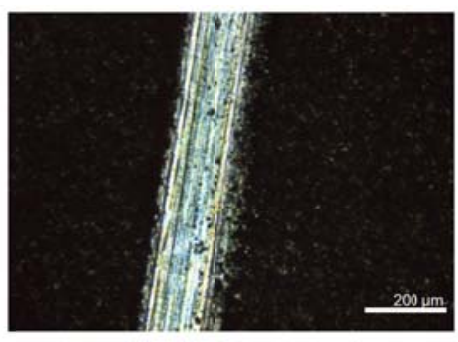

(a)

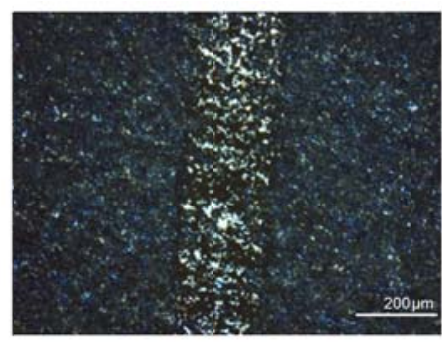

(c)

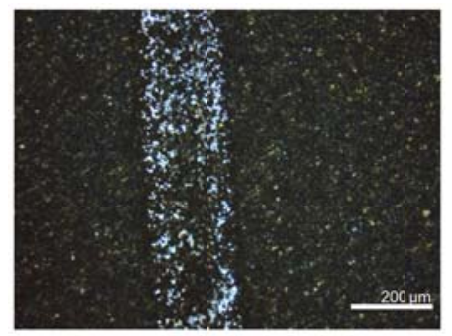

(e)

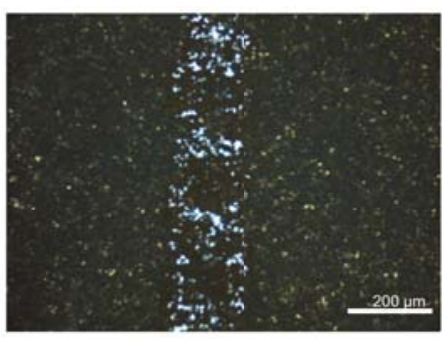

(b)

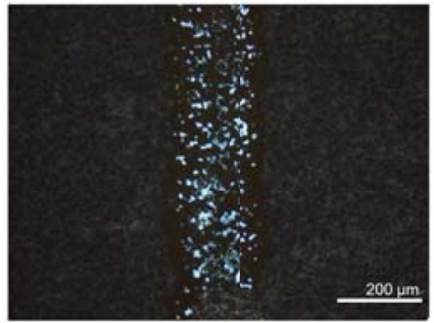

(d)

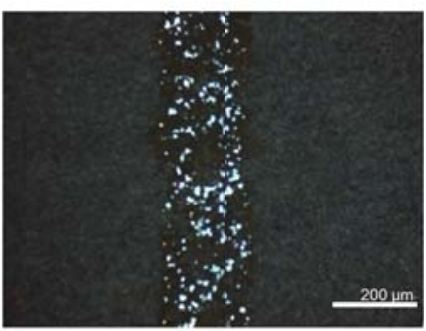

(f)

Figure 4. Optical images of the wear track on disks of (a) gamma-TiAl (c) Ti-6Al-4V and (e) $\mathrm{CP}-\mathrm{Ti}$ oxidized at $500^{\circ} \mathrm{C}$ and (b) gamma-TiAl (d) Ti-6Al-4V and (f) CP-Ti oxidized at $800^{\circ} \mathrm{C}$ when tested against SS pin at $3 \mathrm{~N}$ normal load in a dry medium for 1,200 cycles, $5 \mathrm{~Hz}$ frequency, and $10 \mathrm{~mm}$ displacement.

\subsection{Tests on oxidized samples in lubricated medium}

Figure 5 shows COF data for the titanium materials tested against the stainless steel pin in the lubricated medium where the sample disks were completely immersed in Ringer's solution. In the graphs shown, the COF values vary fairly continuously and remain fairly constant, ranging between 0.4 and 0.8 when compared to the tests conducted in a dry medium. Also in these tests, no mass change was noticeable in the SS ball pins after each run and no deformation was observed after the tests. Furthermore, there is generally little or no mean volume loss of the oxides on the Ti alloy samples after the lubricated tests (see Table 1). There is little change in the mean mass loss for the Ti alloy samples oxidized at $500^{\circ} \mathrm{C}$. Higher values of mean mass loss are calculated for the oxides formed on CP-Ti and Ti-6Al-4V after oxidation at $800^{\circ} \mathrm{C}$ compared to gamma-TiAl in both dry and lubricated tests. From Figure 6, it is generally observed that the wear tracks on the samples after tests in Ringer's solution are deeper when compared to the tracks formed during the dry tests due to the reasons mentioned above. This is especially true for the samples oxidized at $800^{\circ} \mathrm{C}$ where the oxides appear to spall off resulting in relatively larger mean volume and mass loss of the sample. The Ti-6Al-4V samples exhibited brighter and more marked scratches, demonstrating that the SS ball pin penetrated further past the oxide layer and more mass was removed during the tests. Likewise, the wear paths on the CP-Ti samples were even more severely marked. In the case of these last two materials, the oxide layer showed cracks and fracture zones where the oxide had spalled off, whereas such features were not visible on the oxide formed on gamma-TiAl samples which show the lowest volume loss of the three materials that were studied. 


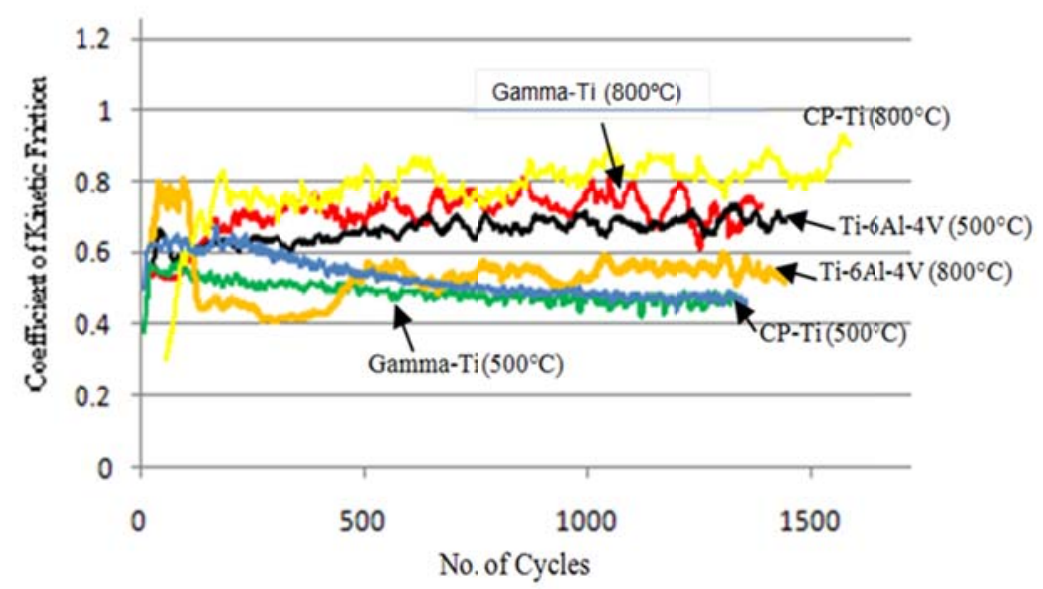

Figure 5. COF versus number of cycles of oxidized Ti-base materials against stainless steel pin at $3 \mathrm{~N}$ normal load in lubricated medium, $5 \mathrm{~Hz}$ frequency, $10 \mathrm{~mm}$ displacement

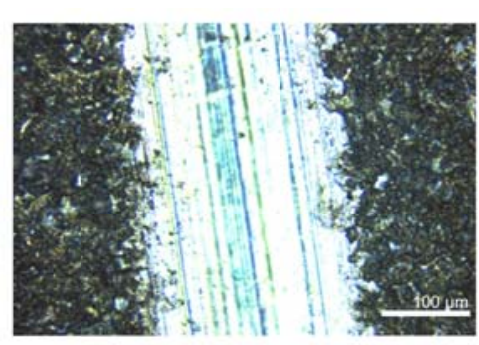

(a)

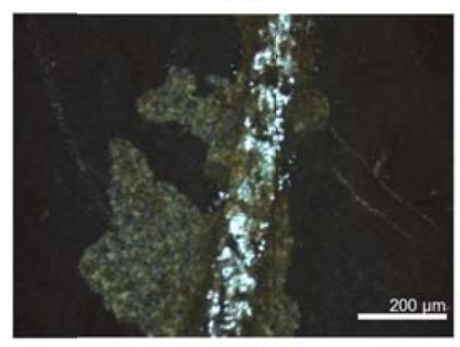

(c)

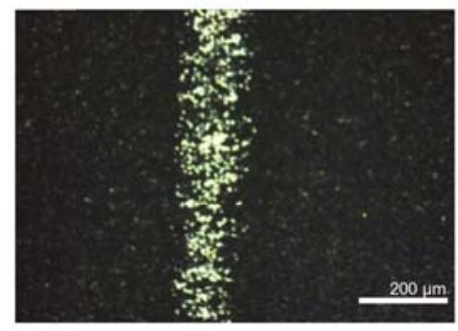

(e)

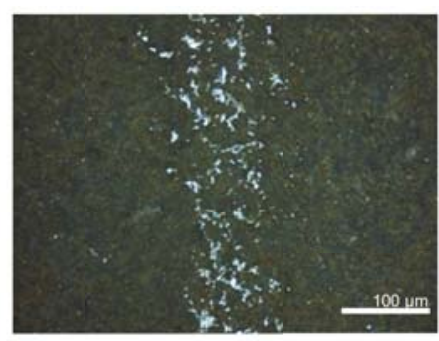

(b)

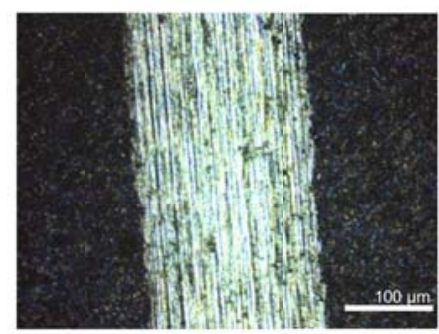

(d)

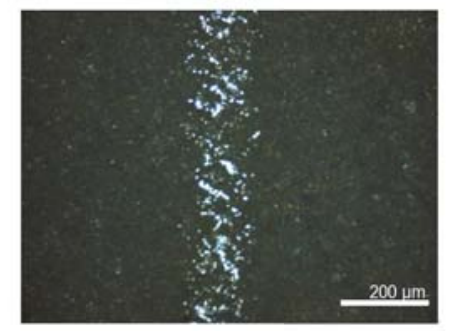

(f)

Figure 6. Optical images of the wear track on disks of (a) gamma-TiAl (c) Ti-6Al-4V and (e) CP-Ti oxidized at $500^{\circ} \mathrm{C}$ and (b) gamma-TiAl (d) Ti-6Al-4V and (f) CP-Ti oxidized at $800^{\circ} \mathrm{C}$. These were tested against SS pin at $3 \mathrm{~N}$ normal load in a lubricated medium (Ringer's solution) for 1,200 cycles, $5 \mathrm{~Hz}$ frequency, and $10 \mathrm{~mm}$ displacement. 


\subsection{Tests on non-oxidized samples in dry medium}

In order to establish an appropriate comparison and differentiate changes in behavior due to oxidation, the surfaces of the three Ti-base materials studied were tested under the same conditions, but without any thermal oxidation treatment (only a thin nanoscale native oxide film is formed on the samples). Figure 7 shows the COF values for the three alloys tested against a SS ball pin in a dry medium where considerable local variation is observed. Since the SS ball pins are harder to wear down compared to the bare Ti-base alloys, more mass is removed uniformly from the alloy samples during each cycle. Also, the wear debris interferes with the movement of the pin, generating the local variations in the COF values. These values are lower than those for the oxidized samples indicating more friction between the oxide-SS pairs compared to bare metal-SS pairs. However, mass loss from the wear tests on the bare metal samples is clearly greater than for the oxide surfaces attesting to the higher hardness of the oxide compared to the bare metal (see Table 2). It is also noted that the gamma-TiAl samples lost 30\% less mass after the wear tests than the Ti-6Al-4V and CP-Ti samples.

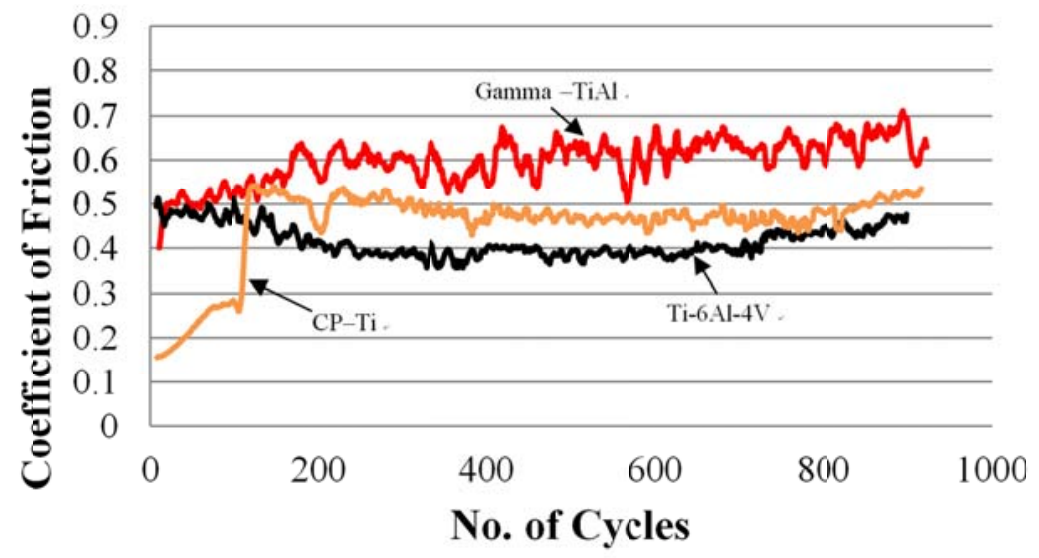

Figure 7. COF versus number of cycles of unoxidized Ti-base materials against stainless steel pin at $3 \mathrm{~N}$ normal load in dry medium, $5 \mathrm{~Hz}$ frequency, $10 \mathrm{~mm}$ displacement.

The wear tracks formed during the tests by the SS ball pin are deeper and wider (see Figure 8) and instead of generating individual scratches as seen in Figure 4 and Figure 6, the area removed by the ball pin is equivalent to the contact area between the SS ball pin and the surface. There were no significant wear particles or mass changes from the SS ball pins after the tests. On the contrary, vast amounts of debris from the Ti-base alloy samples were seen. Also, although no fracture, cracks, pits, oxide and grain pull-out were seen, severe damage was observed on the surface of the samples, specifically to the Ti-6Al-4V and CP-Ti samples. In addition, in the Ti-6Al-4V and CP-Ti disks and as seen in Figure 8, besides the surface scratches, there was also plastic deformation of the surface grains after the wear test, specifically in the CP-Ti samples.

\subsection{Tests on unoxidized samples in lubricated medium}

Figure 9 shows the COF values for the three Ti-base alloys tested against a SS ball pin in a lubricated medium. All three materials show almost constant COF values over a significantly wide range up to almost 1,000 cycles and therefore the fact that lubrication with Ringer's solution reduces the amount of debris formed which minimizes the erratic trend in the values of the COF is underscored. Furthermore, the lubricant reduced the values for the COF obtained, when compared to the dry tests carried out with the SS ball pin. Generally, there was a reduction in the amount of mass removed from the gamma-TiAl and Ti-6Al-4V samples during the lubricated tests compared to the dry tests while the amount of mass lost from the CP-Ti samples remained almost the same. In Figure 8a to 8f, the abundance of scratches seen on almost all the samples that were not intentionally oxidized, indicates abrasion to be the dominant wear mechanism. Also, plastic deformation of the surface grains was seen in the CP-Ti samples, although less than that observed during the dry tests. Debris from the Ti-samples was seen after the tests and no evidence of particle adhesion was observed. 


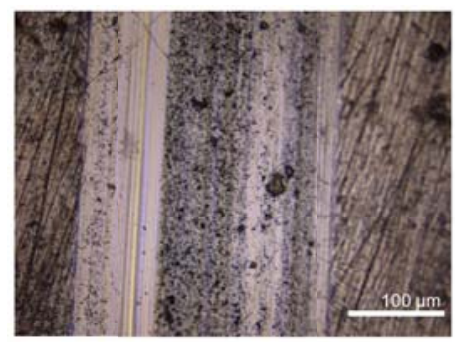

(a)

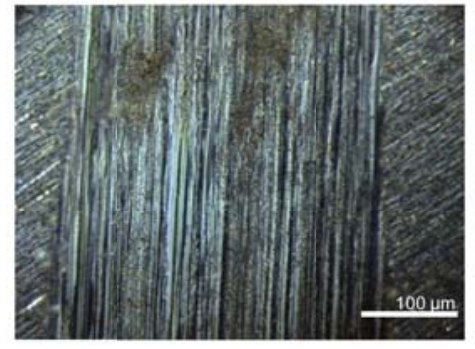

(c)

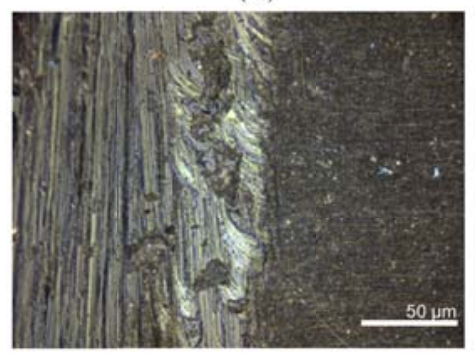

(e)

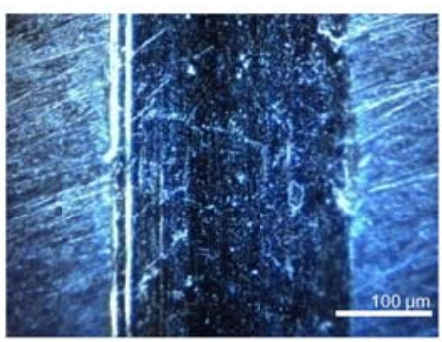

(b)

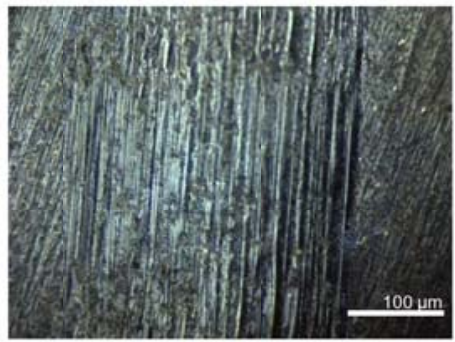

(d)

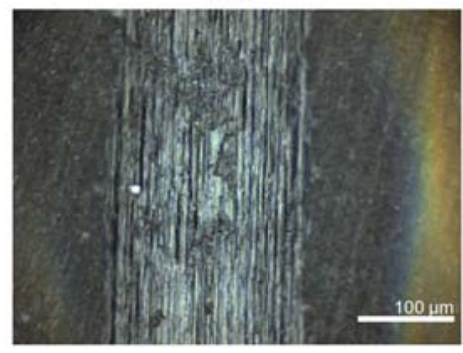

(f)

Figure 8. Optical images of the wear track on unoxidized disks of (a) gamma-TiAl (c) Ti-6Al-4V and (e) CP-Ti under dry conditions and (b) gamma-TiAl (d) Ti-6Al-4V and (f) CP-Ti in a lubricated medium tested against a SS pin at 3N normal load for 1,200 cycles, $5 \mathrm{~Hz}$ frequency, and $10 \mathrm{~mm}$ displacement.

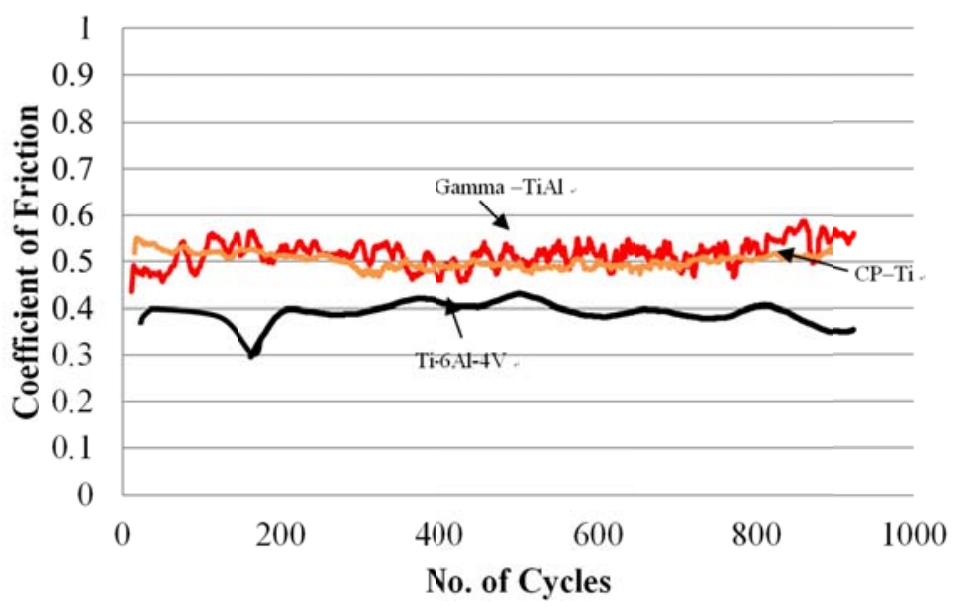

Figure 9. COF versus number of cycles for the Ti-base materials fretted against stainless steel pin at $3 \mathrm{~N}$ normal load in lubricated medium, $5 \mathrm{~Hz}$ frequency, and $10 \mathrm{~mm}$ displacement. 
From the measured mass changes, after the tribology tests, some general patterns were observed in the present study. For all the samples (oxidized and non-oxidized samples in lubricated and dry media) studied, the gamma-TiAl samples treated at both temperatures $\left(500^{\circ} \mathrm{C}\right.$ and $\left.800^{\circ} \mathrm{C}\right)$ and also in the non-oxidized control group exhibited the least amount of mass loss. Mean mass loss was greater for the Ti alloy samples oxidized at $800^{\circ} \mathrm{C}$ as expected since the oxide formed was more porous and susceptible to spallation. As expected, this is the result of a thicker layer of porous oxide formed at the higher temperature which is relatively brittle. Also, the mixed aluminum oxide layer is possibly harder than the titanium oxide layer although hardness values were not obtained. In addition, a larger amount of mass loss was measured after wear tests performed on the bare metal surfaces in both lubricated and dry media against a SS ball pin for all three Ti-base materials compared to the oxidized samples. More specifically, in the case of the gamma-TiAl samples, despite taking into account the amount of oxide formed after the thermal treatments with the extremely rough surface topography, the resulting minimum mass loss indicates the highest wear resistance of the three alloys and proves that gamma-TiAl alloy possesses excellent wear properties against a SS pin.

Miyoshi et al. studied the wear behavior of oxidized Ti-48Al-2Nb-2Cr under fretting contact in a dry medium with an applied force of $1 \mathrm{~N}-40 \mathrm{~N}^{[26]}$. The wear scars produced on Ti-48Al-2Cr-2Nb during these tests contained metallic and oxide wear debris. In addition, scratches, plastically deformed asperities, cracks, and fracture pits were observed in and around the contact areas in the oxide layers for samples oxidized at $550^{\circ} \mathrm{C}$. In the current study, scratches, oxide wear debris and fracture pits were seen for Ti-6Al-4V and CP-Ti oxidized at both temperatures although these were more severe for oxidation at $500^{\circ} \mathrm{C}$. In contrast, no plastic deformation or cracks were noted on the gamma-TiAl samples for either of the treatment temperatures. Moreover, no fractures were seen within or around the contact area.

Abrasion was severe from the wear debris in the current study. The hard asperities and trapped wear particles plow or cut the Ti-alloy surfaces, generating a number of scratches on the surfaces. These also carry part of the load causing concentrated pressure peaks/holes on most of the sample surfaces. The origin of crack nucleation in the oxide layers can be attributed to the pressure peaks. The results from the present study performed with the oxidized samples are in agreement with the abrasion mechanism proposed by Choubey et al. on non-oxidized Ti-6Al-4V and CP-Ti alloys tested in a simulated body fluid against a SS pin ${ }^{[27]}$.

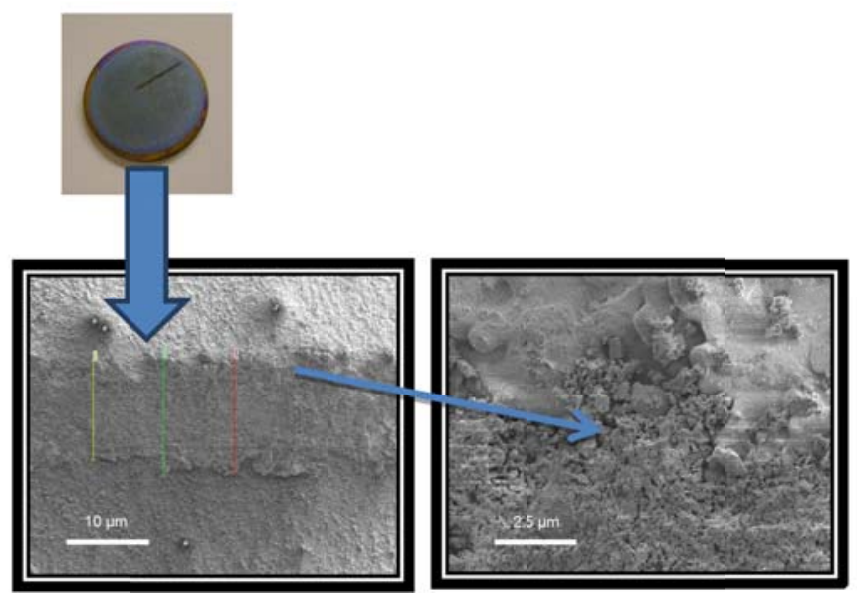

(a)

(b)

Figure 10. SEM images of (a) non-lubricated track (gamma-TiAl oxidized at $500^{\circ} \mathrm{C}$ ) with SS ball pin and (b) track and oxide interface.

The wear scar of a gamma-TiAl sample treated at $500^{\circ} \mathrm{C}$ is shown in Figure 10a from which a fairly uniform and compact surface of the wear track is visible after the wear. During the wear tests, the pin arm deflected up and down more on this 
surface than on the other materials for both oxidation treatments. The variation in the COF values appears to be caused by the adhesion of wear debris onto the wear track (which can be appreciated at a higher magnification in Figure 10b due to the existence of low temperature welding of wear particles onto the track which was confirmed by the presence of steel in the composition of the wear paths. The results can be appreciated in EDS data in Figure 11 where the spectra from the wear tracks in the Ti-samples included attached debris from the SS ball pins represented by the Fe peaks. This behavior was seen in all the Ti-alloys after the wear tests against SS and explains the lack of smoothness in the COF graphs. Although the existence of SS debris on the oxidized samples was confirmed, no measureable weight change in the SS pins was noted after the wear tests, although from Figure 12 some removal of mass from the surface of the SS ball pins is visible as pits.

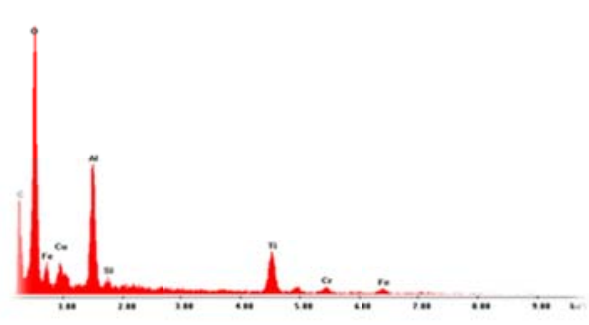

(a)

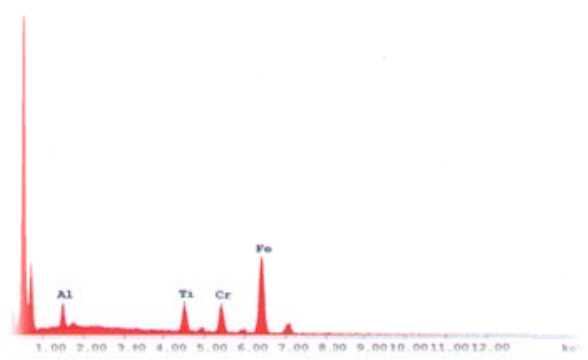

(b)

Figure 11. Energy dispersive spectra of wear track in (a) CP-Ti sample oxidized at $800^{\circ} \mathrm{C}$ in a lubricated medium and (b) gamma-TiAl sample oxidized at $800^{\circ} \mathrm{C}$ in dry medium against SS pin indicating the mechanism of adhesive wear through the presence of Fe peaks.

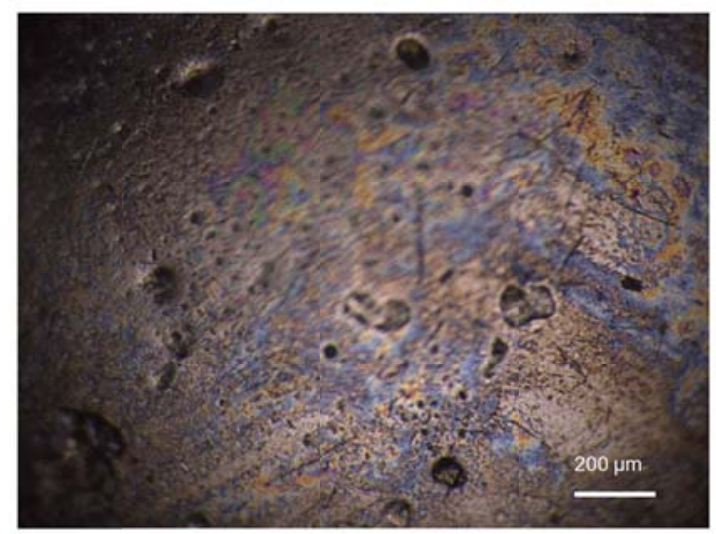

Figure 12. Optical image of SS ball pin surface after wear tests against gamma-TiAl samples oxidized at $800^{\circ} \mathrm{C}$ in dry medium. Note the gouged regions on the SS pin surface.

In the standardized lubricated tests with the SS ball pin, the Ti-base alloys lost more mass than in the dry tests. Many studies associate a high value of the coefficient of friction to a low wear resistance or high mass loss ${ }^{[26,28]}$. Since the samples in this study exhibited more mass loss in Ringer's solution than the samples tested in a dry medium, larger values for COF were expected. In reality, the COF values were actually the lowest in the entire study. This is a result of the good lubrication provided by the Ringer's solution and the innate lubricity of native $\mathrm{TiO}_{2}$ formed on the alloy surfaces ${ }^{\text {[27] }}$. Nevertheless, the highest COF values were measured for gamma-TiAl compared to the other Ti-base alloys. In the images of the wear tracks from the lubricated tests as seen in Figure 13a, gamma-TiAl oxidized at $500^{\circ} \mathrm{C}$, abrasive marks are clearly seen whereas for the samples oxidized at $800^{\circ} \mathrm{C}$ there were small regions within the wear track where surface grains were eliminated as in Figure 13b. Although some grains were pulled out during the wear tests, the majority of the 
oxide was kept intact. The oxidized gamma-TiAl alloys possess the highest wear resistance in agreement with the data in Table 2 where gamma-TiAl shows the smallest amount of mass loss after the wear tests.

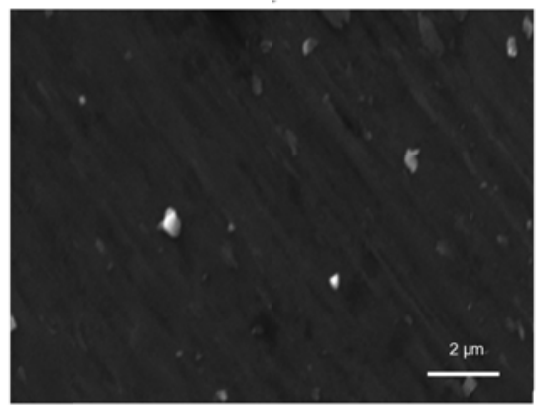

(a).

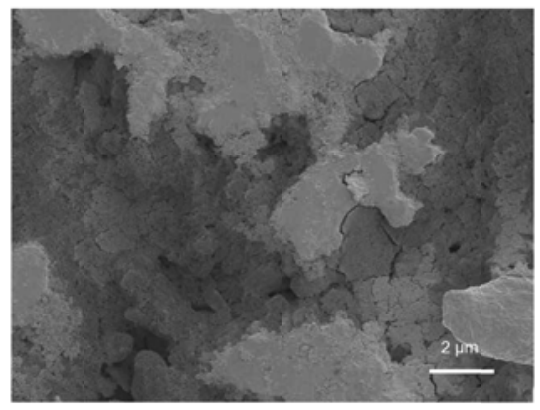

(b)

Figure 13. SEM image of wear track on gamma-TiAl oxidized at (a) $500^{\circ} \mathrm{C}$ and (b) $800^{\circ} \mathrm{C}$ under lubricated conditions against a SS pin.

Both under dry and lubricated environments, the effect of oxidation temperature was observed on the samples. This was significant in the case of Ti-6Al-4V and CP-Ti specimens; the mass losses at $800^{\circ} \mathrm{C}$ were between $1.5-2$ times of those at $500^{\circ} \mathrm{C}$. In the case of gamma-TiAl, this difference was significantly smaller. Surface and in some cases subsurface damage occurred on the interacting surfaces of all the other titanium alloys tested in both dry and lubricated media consisting of material transfer, pits, grain pull out, scratches, fretting craters and/or wear scars and cracks. Scratches were observed on the surface of the unoxidized gamma-TiAl after being tested in lubricated and non-lubricated conditions (see Figure 14). The main difference between both cases is the larger number of the scratches for testing in a dry medium.

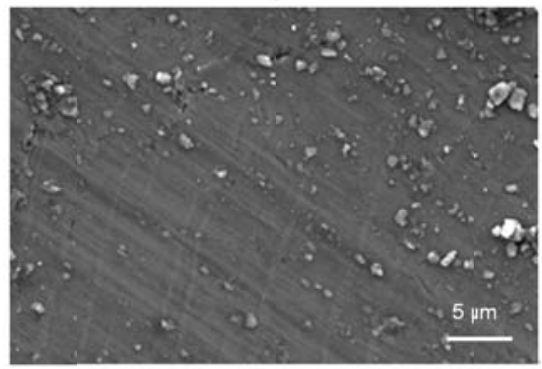

(a)

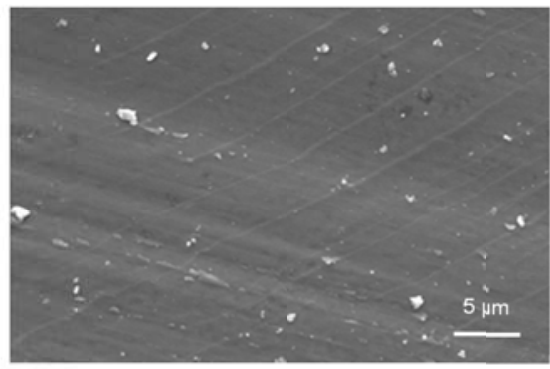

(b)

Figure 14. Surface topography of unoxidized gamma-TiAl (a) after wear testing in dry medium and (b) after wear testing in Ringer's solution.

\section{Conclusions}

Gamma-TiAl disks were oxidized at $500^{\circ} \mathrm{C}$ and $800^{\circ} \mathrm{C}$ and the wear properties of the respective oxide layers were determined under dry and lubricated conditions and compared to Ti-6Al-4V and CP-Ti, two alloys currently used in implant applications. From the results of this study, the following conclusions are made:

1) The least amount of mass loss after the wear test both in dry and lubricated media and both for oxidized and unoxidized surfaces were observed for gamma-TiAl. Wear damage was also less severe for this alloy compared to the other two materials.Thus oxidized gamma-TiAl possesses the highest wear resistance among the materials investigated. 
2) Abrasion was the dominant wear mechanism under all conditions that were studied.

3) The effect of oxidation temperature on the mass loss was significant for Ti-6Al-4V and CP-Ti but almost negligible for gamma-TiAl under both dry and lubricated environments.

\section{References}

[1] Harris WH. The problem is osteolysis. Clin Orthop Rel Res. 1995; 211: 46-53. PMid:7634590.

[2] Wimhurst JA, Brooks R, Rushton N. The effects of particulate bone cements at the bone-implant interface. J Bone Joint Surg Br. 2001; 83: 588-92. PMid:11380137. http://dx.doi.org/10.1302/0301-620X.83B4.10513

[3] Böhler M, Kanz F, Schwarz B, et al. Adverse tissue reactions to wear particles from Co-alloy articulations, increased by alumina-blasting particle contamination from cementless Ti-based total hip implants. J Bone Joint Surg Br. 2002; 84: 128-36. PMid:11837818. http://dx.doi.org/10.1302/0301-620X.84B1.11324

[4] Witt JD, Swann M. Metal wear and tissue response in failed titanium alloy total hip replacements. J Bone Joint Surg Br. 1991; 73: 559-63. PMid:2071635.

[5] Abu-Amer Y, Darwech I, Clohisy JC. Aseptic loosening of total joint replacements: mechanisms underlying osteolysis and potential therapies. Arthritis Res Ther. 2007; 9: S6. PMid:17634145. http://dx.doi.org/10.1186/ar2170

[6] Diebold U. The surface science of titanium dioxide. Surf Sci Rep. 2003; 48: 53-229. http://dx.doi.org/10.1016/S0167-5729(02)00100-0

[7] Konttinen YT, Milošev I, Trebše R, et al. Metals for joint replacement, in: P.A. Revell (Ed.). Joint Replacement Technology. CRC Press, USA. 2008. http://dx.doi.org/10.1533/9781845694807.2.115

[8] Agins HJ, Alcock NW, Bansal M, et al. Metallic wear in failed titanium-alloy total hip replacement. A histological and quantitative analysis. J Bone Joint Surg. 1988; 70A: 347-56.

[9] Buchanan RA, Rigney Jr. ED, Williams JM. Wear-accelerated corrosion of Ti-6Al-4V and nitrogen-ion implanted Ti-6Al-4V: Mechanisms and influence of fixed-stress magnitude. J Biomed Mater Res. 1987; 21: 367-77. PMid:3558450. http://dx.doi.org/10.1002/jbm.820210309

[10] Lombardi Jr. AV, Mallory TH, Vaughn BK, et al. Aseptic loosening in total hip arthroplasty secondary to osteolysis induced by wear debris from titanium-alloy modular femoral heads. J Bone Joint Surg. 1989; 71A: 1337-42.

[11] Davies JE. Mechanisms of endosseous integration. Int J Prosthodont. 1998; 11: 391-401. PMid:9922731.

[12] Berglundh T, Abrahamsson I, Lang NP, et al. De novo alveolar bone formation adjacent to endosseous implants. Clin Oral Implan Res. 2003; 14: 251-62. http://dx.doi.org/10.1034/j.1600-0501.2003.00972.x

[13] Albrektsson T, Wennerberg A. Oral implant surfaces-Review focusing on clinical knowledge of different surfaces. Int J Prosthodont. 2004; 17: 544-64. PMid:15543911.

[14] Esposito M, Coulthard P, Thomsen P, et al. The role of implant surface modifications, shape and material on the success of osseointegrated dental implants. Eur J Prosthodont Restor Dent. 2005; 13: 15-31. PMid:15819145.

[15] Puleo D, Thomas MV. Implant Surfaces. Dent Clin N Am. 2006; 50: 323-38. PMid:16818018. http://dx.doi.org/10.1016/j.cden.2006.03.001

[16] Guehennec L, López-Heredia MA, Enkel B, et al. Osteoblastic cell behavior on different titanium implant surfaces. Acta Biomater. 2008; 14: 535-43. PMid:18226985. http://dx.doi.org/10.1016/j.actbio.2007.12.002

[17] Delgado C, Sundaram PA. Corrosion evaluation of Ti-48Al-2Cr-2Nb (at. \%) in Ringer's solution. Acta Biomater. $2006 ; 2: 701-8$. PMid:16887397. http://dx.doi.org/10.1016/j.actbio.2006.05.012

[18] Rivera-Denizard O, Diffoot-Carlo N, Navas V, et al. Biocompatibility studies of human osteoblast cells cultured on gamma titanium aluminide. J Mat Sci Mat Med. 2008; 19: 153-8. PMid:17597368. http://dx.doi.org/10.1007/s10856-006-0039-4

[19] Castañeda-Muñoz DF, Sundaram PA, Ramirez N. Bone tissue reaction to Ti-48Al-2Cr-2Nb (at. \%) in a rodent model: a preliminary SEM study. J Mat Sci Mat Med. 2007; 18: 1433-8. PMid:17387593. http://dx.doi.org/10.1007/s10856-006-0095-9

[20] Bello SA, De Jesus-Maldonado I, Rosim-Facchini E, et al. In vitro evaluation of human osteoblast adhesion to a thermally oxidized $\gamma$ TiAl intermetallic alloy of composition Ti-48Al-2Cr-2Nb (at. \%). J Mat Sci Mat Med. 2010; 21: 1739-50. PMid:20162332. http://dx.doi.org/10.1007/s10856-010-4016-6

[21] Rastkar AR, Bloyce A, Bell T. Sliding wear behaviour of two gamma-based titanium aluminides. Wear. 2000; $240: 19-26$. http://dx.doi.org/10.1016/S0043-1648(00)00334-3

[22] Rastkar AR, Bell T. Characterization and tribological performance of oxide layers on a gamma based titanium aluminide. Wear. 2005; 258: 1616-24. http://dx.doi.org/10.1016/j.wear.2004.11.014 
[23] Rastkar AR, Shokri B, Bell T. Structural and mechanical evaluation of the effect of oxygen boost diffusion on a gamma based titanium aluminide of Ti-45Al-2Nb-2Mn-1B. Surf Coat Tech. 2008; 202: 6038-48. http://dx.doi.org/10.1016/j.surfcoat.2008.07.001

[24] Ramos-Saenz CR, Sundaram PA, Diffoot-Carlo N. Tribological properties of Ti-based alloys in a simulated bone-implant interface with Ringer’s solution at fretting contacts. J Mech Behav of Biomed Mater. 2010; 3: 549-58. PMid:20826360. http://dx.doi.org/10.1016/j.jmbbm.2010.06.006

[25] Fergus JW. Review of the effect of alloy composition on the growth rates of scales formed during oxidation of gamma titanium aluminide alloys. Mater Sci Eng A. 2002; 338: 108-25. http://dx.doi.org/10.1016/S0921-5093(02)00064-3

[26] Miyoshi K, Lerch BA, Draper SL, et al. Fretting Fatigue: Advances in Basic Understanding and Applications. ASTM STP 1425, Mutoh Y, Kinyon SE and Hoeppner DW, Eds. American Society for Testing and Materials. West Conshohocken, PA. 2003; 323-37. http://dx.doi.org/10.1520/STP10768S

[27] Choubey A, Basu B, Balasubramaniam R. Tribological behavior of Ti-based alloys in a simulated body fluid solution at fretting contacts. Mater Sci Eng A. 2004; 379: 234-9. http://dx.doi.org/10.1016/j.msea.2004.02.027

[28] Mustafa K, Wennerberg A, Wroblewski J, et al. Determining optimal surface roughness of $\mathrm{TiO}_{2}$ blasted titanium implant material for attachment, proliferation and differentiation of cells derived from human mandibular alveolar bone. Clin Oral Implants Res. 2001; 12: 515-25. PMid:11564113. http://dx.doi.org/10.1034/j.1600-0501.2001.120513.x 